\title{
Interactive Short-term Effects of Waterlogging and Salinity Stress on Growth and Carbohydrate, Lipid Peroxidation, and Nutrients in Two Perennial Ryegrass Cultivars
}

\author{
Xiujie Yin and Chao Zhang \\ Department of Grass Science, College of Animal Science and Technology, Northeast Agricultural \\ University, Harbin, Heilongjiang Province, 150030, P.R. China \\ Xin Song \\ State Key Laboratory of Grassland Agro-ecosystems, College of Pastoral Agriculture Science and \\ Technology, Lanzhou University, Lanzhou, 730000, P.R. China; and Department of Agronomy, \\ Purdue University, West Lafayette, IN 47907 \\ Yiwei Jiang ${ }^{1}$ \\ Department of Agronomy, Purdue University, West Lafayette, IN 47907
}

\begin{abstract}
AdDitional INDEX words. flooding, ion element, Lolium perenne, physiology, salt
Abstract. Waterlogging can occur in salt-affected turfgrass sites. The objective of this study was to characterize growth and carbohydrate, lipid peroxidation, and nutrient levels in the leaves and roots of two perennial ryegrass (Lolium perenne) cultivars (Catalina and Inspire) to short-term simultaneous waterlogging and salinity stress. Previous research showed that 'Catalina' was relatively more tolerant to salinity but less tolerant to submergence than 'Inspire'. Both cultivars were subjected to 3 and 7 days of waterlogging (W), salinity [S (300 mM NaCl)], and a combination of the two stresses (WS). Across the two cultivars, W alone had little effect on the plants, while both $S$ and WS alone significantly decreased plant height (HT), leaf fresh weight (LFW), leaf dry weight (LDW), root fresh weight (RFW), root dry weight (RDW), leaf nitrogen (LN) and carbon (LC), and leaf and root $\mathrm{K}^{+}\left(\mathrm{RK}^{+}\right)$, and increased leaf water-soluble carbohydrate (LWSC) and root water-soluble carbohydrate (RWSC), malondialdehyde (MDA), and $\mathrm{Na}^{+}$content, compared with the control. A decline in chlorophyll content (Chl) was found only at 7 days of WS. Leaf phosphorus (LP) content either decreased or remained unchanged but root phosphorus content increased under $S$ and WS. Reductions in LFW and LDW were found at 3 days of S and WS, whereas RFW and RDW were unaffected until 7 days of $S$ or WS. Both cultivars responded similarly to W, S, and WS with a few exceptions on RDW, LWSC, leaf MDA (LMDA), and root MDA (RMDA). Although WS caused declines in Chl and resulted in higher leaf $\mathrm{Na}^{+}\left(\mathrm{LNa}^{+}\right)$and root $\mathrm{Na}^{+}\left(\mathrm{RNa}^{+}\right)$than $\mathrm{S}$ at 7 days of treatment, $\mathrm{S}$ and WS had similar effects on growth, carbohydrate, MDA, $\mathrm{N}, \mathrm{C}$, and phosphorus, and $\mathrm{K}^{+}$content across the two cultivars. The results suggested that $\mathrm{S}$ alone largely accounted for the negative effects of WS on plant growth and physiology including alteration of carbohydrate and nutrient content as well as induction of lipid peroxidation.
\end{abstract}

Waterlogging and salinity are common stresses that largely affect turfgrass growth and physiology. Waterlogging reduces soil aeration and leads to oxygen deficiency in the roots. Previous studies showed that growth and physiological responses of turf plants to waterlogging vary with plant species, cultivars, stress duration, and severity (Huang et al., 1998; Jiang and Wang, 2006; Liu and Jiang, 2015; Wang and Jiang, 2007a, 2007b; Zong et al., 2015). Waterlogging reduced growth, chlorophyll content, RWSC content, soluble protein content, and increased root electrolyte leakage and lipid peroxidation, and decreased or increased activities of antioxidant enzymes in shoots and roots of kentucky bluegrass (Poa pratensis), perennial ryegrass, and creeping bentgrass (Agrostis stolonifera) (Huang et al., 1998; Jiang and Wang, 2006; Liu and Jiang, 2015; Wang and Jiang, 2007a, 2007b). Even partial waterlogging (water occurring at 15 to $5 \mathrm{~cm}$ below soil surface) could

This research was supported by Heilongjiang Province Science Foundation of China (C2015019).

${ }^{1}$ Corresponding author. E-mail: yjiang@purdue.edu. substantially affect creeping bentgrass growth and carbohydrate content (Jiang and Wang, 2006). Waterlogging also decreased root oxidase activity and altered metabolic activities in warm-season turfgrass species including knotgrass (Paspalum paspaloides), spiny mudgrass (Pseudoraphis spinescens), seashore paspalum (Paspalum vaginatum), and centipedegrass (Eremochloa ophiuroides) (Zong et al., 2015). Differential stress responses of plants to waterlogging may reflect diverse mechanisms of plant survival.

Salinity affects plant growth and development generally through osmotic stress limiting water uptake and the excessive uptake of ions causing ion toxicity such as $\mathrm{Na}^{+}$(Munns and Tester, 2008). The effects of salinity on plant growth and metabolic activities vary highly among turfgrass species, cultivar, or accessions within a species as well as salinity concentration. Seashore paspalum had superior shoot dry weight under salinity stress compared with zoysiagrass (Zoysia japonica), manila grass (Zoysia matrella), hybrid bermudagrass (Cynodon dactylon $\times$ C. transvaalensis), and serangoon grass (Digitaria didactyla), although inhibition of growth occurred in 
all species exposed to salinity (Uddin et al., 2012). Within a species, decreased plant HT occurred at lower salinity concentrations $(>50 \mathrm{~mm} \mathrm{NaCl})$, whereas reductions in LDW, leaf water content, chlorophyll fluorescence, and increase in WSC content occurred at $>150 \mathrm{~mm} \mathrm{NaCl}$ in 10 perennial ryegrass accessions (Tang et al., 2013a). Germplasm of perennial ryegrass accessions exhibited large variations of salinity tolerance when plants were exposed to $300 \mathrm{~mm} \mathrm{NaCl}$ (Tang et al., 2013b). Salinity stress also causes an imbalance of nutrition and frequently decreases in absorption of $\mathrm{K}^{+}, \mathrm{NO}_{3}{ }^{-}$, and phosphate (Pi) (Shokri and Maadi, 2009). However, alterations of $\mathrm{Na}^{+}$and $\mathrm{K}^{+}$along with other nutrients such as $\mathrm{N}$ and $P$ in relation to salinity tolerance are not well understood in turfgrass species.

In salt-affected sites, plants can potentially be subjected to waterlogging stress, particularly for those plants growing in coastal and flood-prone plains where frequent flooding stress may occur. The simultaneous waterlogging and salinization could have more adverse consequences for growth than from waterlogging or salinity alone. Simultaneous waterlogging and salinity stress reduced shoot and root biomass (Aini et al., 2012; Jenkins et al., 2010) and $\mathrm{K}^{+}$content (Barrett-Lennard and Shabala, 2013; Horchani et al., 2010), and increased shoot $\mathrm{Na}^{+}$, $\mathrm{Cl}^{-}$, and proline content in other plant species (Aini et al., 2012; Barrett-Lennard and Shabala, 2013; Bhuiyan et al., 2015; Horchani et al., 2010; Teakle et al., 2006). It is speculated that the mechanisms for waterlogging or salinity tolerance may be beneficial for plants to survive simultaneous waterlogging and salinity stress. For example, under high salinity (400 to $500 \mathrm{~mm}$ $\mathrm{NaCl}$ ), a salinity-tolerant species of sweet clover (Melilotus siculus) had higher shoot dry weight than bigflower clover (Trifolium michelianum) with low-to-moderate salinity tolerance but high waterlogging tolerance, but it was also tolerant to combined salinity and waterlogging by maintaining higher root porosity and regulation of shoot $\mathrm{Na}^{+}$and $\mathrm{Cl}^{-}$(Teakle et al., 2012). Within the tolerant sweet clover, the capacity of tolerance to combined salinity and root-zone hypoxia was mediated by regulating ions and was not related to variation in root porosity (Striker et al., 2015). A higher shoot dry weight and lower $\mathrm{Na}^{+}$found in alkali grass (Puccinellia ciliata) compared with tall wheatgrass (Thinopyrum ponticum) led to substantial differences in their growth under saline/waterlogged conditions (Jenkins et al., 2010). Although the separate effects of waterlogging or salinity stress on turfgrass species and cultivars have been reported, little is known about responses of turf plants to a combination of the two stresses. A comparison of germination and shoot and root dry weight of four turfgrass species subjected to waterlogging combined with salinity stress demonstrated that tall fescue (Schedonorus arundinaceus) had better tolerance to both salinity and waterlogging stresses than kentucky bluegrass, blue grama (Bouteloua gracilis), and buffalograss (Bouteloua dactyloides) (Zhang et al., 2013). However, interactive effects of waterlogging and salinity stress on turfgrass growth and physiology have not been well documented.

Perennial ryegrass is a popular and important cool-season turf, forage, and pasture grass that is widely used around the world. Some cultivars and wild accessions of this species differed in salinity tolerance (Tang et al., 2013a, 2013b), waterlogging or submergence tolerance (Liu and Jiang, 2015; $\mathrm{Yu}$ et al., 2012). But little is known about the growth and physiological responses of perennial ryegrass cultivars to simultaneous waterlogging and salinity stress. The objective of this study was to characterize growth and carbohydrate, lipid peroxidation, and nutrient levels of two perennial ryegrass cultivars to short-term simultaneous waterlogging and salinity stress. Through investigation of leaf and root responses to stress conditions, this study would reveal the tolerance mechanisms of perennial ryegrass to short-term waterlogging combined with salinity stress.

\section{Materials and Methods}

Plant materials and growth conditions. Perennial ryegrass cultivars Inspire and Catalina were used for the experiment. 'Catalina' was more salinity tolerant than 'Inspire' by maintaining higher LDW and leaf $\mathrm{K}^{+} / \mathrm{Na}^{+}$(Tang et al., 2013b), while 'Inspire' was more tolerant to submergence than 'Catalina' by showing lesser reductions in leaf color and growth rate (Yu et al., 2012). About 90 seeds $(0.15 \mathrm{~g})$ were sown in sand in plastic pots ( $4 \mathrm{~cm}$ diameter, $9 \mathrm{~cm}$ deep) in a greenhouse on 17 Sept. 2015 at Purdue University, West Lafayette, IN. Plants were watered twice per week with a $50 \mathrm{~mL}$ half-strength Hoagland solution and cut once per week to $5 \mathrm{~cm}$. The average temperatures in the greenhouse were $20 \pm 1.5 / 17 \pm 1.0{ }^{\circ} \mathrm{C}$ (day/night), with a relative humidity of $65 \%$. The photosynthetically active density was $\approx 400 \mu \mathrm{mol} \cdot \mathrm{m}^{-2} \cdot \mathrm{s}^{-1}$, with a 10 -h light period of natural and artificial light.

Waterlogging and SALinity treatments. All plants were cut to the same HT of $5 \mathrm{~cm}$ before stress treatments. On 8 Jan. 2016, stress treatments were initiated and plants were subjected to the following four treatments: 1) control, 2) waterlogging, 3) salinity, and 4) simultaneous waterlogging and salinity. For the control, plants were watered daily with $50 \mathrm{~mL}$ half-strength Hoagland solution and free drainage was allowed at the bottom of the pots. The waterlogging treatment was imposed by placing pots into plastic containers $(58 \mathrm{~cm}$ length $\times 35 \mathrm{~cm}$ width $\times 28 \mathrm{~cm}$ depth) with Hoagland solution kept at the soil surface of the pots. Salinity treatment was imposed by irrigating plants daily with Hoagland solution amended with $300 \mathrm{~mm}$ $\mathrm{NaCl}$. To avoid salinity shock, plants were previously exposed to a gradually increasing $\mathrm{NaCl}$ concentration for $7 \mathrm{~d}$ (from 1 Jan. 2015 to 7 Jan. 2015) until reaching the final concentration. For the waterlogging combined with salinity treatment, the salt-treated plants were placed into the containers and Hoagland solution amended with $300 \mathrm{~mm} \mathrm{NaCl}$ was kept at the soil surface of each pot. All pots for the four treatments were placed in the same size containers, described above, for maintaining experimental uniformity.

SAMPling AND MEASUREments. Plants were harvested at 3 and $7 \mathrm{~d}$ of treatments and roots were washed free of sand. The absolute plant HT grown during the four treatment phases was recorded to identify growth during the period of stresses. A portion of the leaf and root tissues was dried in an oven at $80^{\circ} \mathrm{C}$ to determine dry weight. A portion of the leaves was randomly selected for chlorophyll extraction. Leaf Chl was extracted by soaking $\approx 50 \mathrm{mg}$ leaf samples in $15 \mathrm{~mL}$ dimethyl sulfoxide in the dark for $48 \mathrm{~h}$. The absorbance was then read at 665 and $649 \mathrm{~nm}$ and the concentration of Chl was calculated using the method of Wellburn (1994).

Total WSC was measured using the anthrone method (Koehler, 1952) with some modifications (Yu et al., 2012). Briefly, WSC was extracted from $\approx 50 \mathrm{mg}$ fine powder of dry leaf or root tissues with $1 \mathrm{~mL}$ double-distilled water. The extract was shaken for $10 \mathrm{~min}$ and centrifuged at $11,000 \mathrm{~g}_{\mathrm{n}}$ for 
$10 \mathrm{~min}$, and the supernatant was collected. The extraction was repeated three more times and the supernatant was pooled. A 1-mL aliquot of extract was mixed with $7 \mathrm{~mL}$ freshly prepared anthrone [200 $\mathrm{mg}$ anthrone $+100 \mathrm{~mL} \mathrm{72 \%}$ (w/w) $\mathrm{H}_{2} \mathrm{SO}_{4}$ ] and placed in a boiling water bath for $8 \mathrm{~min}$. After cooling, the absorbance at $625 \mathrm{~nm}$ was read. The standard curve was determined using glucose in a range of 0 to $300 \mu \mathrm{g} \cdot \mathrm{mL}^{-1}$.

About $50 \mathrm{mg}$ leaf or root powder was mixed with $1 \mathrm{~mL}$ of extraction buffer (50 mM potassium phosphate, $1 \mathrm{~mm}$ ethylenediaminetetraacetic acid, 1\% polyvinylpyrrolidone, $\mathrm{pH} 7.8$ ). The mixture was centrifuged at $15,000 \mathrm{~g}_{\mathrm{n}}$ for $2 \times 15 \mathrm{~min}$ at $4{ }^{\circ} \mathrm{C}$, and the supernatant was collected for MDA analysis. Lipid peroxidation was measured in terms of MDA content (an end product of lipid peroxidation) (Dhindsa et al., 1981), with some modifications (Liu and Jiang, 2015). A $0.5-\mathrm{mL}$ aliquot of the supernatant was mixed with $2 \mathrm{~mL}$ of $20 \%$ trichloroacetic acid containing $0.5 \%$ thiobarbituric acid. The mixture was heated at $95{ }^{\circ} \mathrm{C}$ for $30 \mathrm{~min}$, quickly cooled, and then centrifuged at $10,000 g_{\mathrm{n}}$ for $10 \mathrm{~min}$. The absorbance was read at 532 and $600 \mathrm{~nm}$ (Heath and Packer, 1968). The concentration of MDA was calculated using an extinction coefficient of $155 \mathrm{~mm} \cdot \mathrm{mm}^{-1}$.

About $30 \mathrm{mg}$ of ground leaf or root samples was analyzed in a dry combustion analyzer (CHN 2000; Leco Corp., St. Joseph, MI) equipped with infrared cell and thermal conductivity detectors for $\mathrm{C}$ and $\mathrm{N}$ concentrations, respectively. For phosphorus, $\mathrm{K}^{+}$, and $\mathrm{Na}^{+}$measurements, a 50-mg powder of dry leaf or root tissue was mixed with $3 \mathrm{~mL} 18 \mathrm{M} \mathrm{H}_{2} \mathrm{SO}_{4}$ in a digestion tube. After heating and cooling, $3 \mathrm{~mL}$ of $30 \% \mathrm{H}_{2} \mathrm{O}_{2}$ was slowly added to each tube and the tubes were heated again. This step was repeated until the mixture was clear. The extract was diluted to $50 \mathrm{~mL}$ with distilled water. The final diluted extract was used for the determination of phosphorus, $\mathrm{K}^{+}$, and $\mathrm{Na}^{+}$ concentrations using a plasma atomic emission spectrometer (ICP 9820; Shimadzu, Columbia, MD).

Data Analysis. The experiment was a split-plot design with three replications. The main plot was the treatments and the subplot was the cultivars. The pots were randomly assigned into the containers within the control, waterlogging, salinity, and waterlogging plus salinity treatments. The analysis of variance was performed using SAS (version 9.1; SAS Institute, Cary, NC).

\section{Results}

Analysis of Variance. Across the two cultivars, significant treatment effects were found for all traits except for Chl, RFW, RDW at $3 \mathrm{~d}$ and for root nitrogen (RN) and root carbon (RC) at both 3 and $7 \mathrm{~d}$ of stress. The cultivar effects were observed for $\mathrm{LFW}, \mathrm{LDW}, \mathrm{LWSC}, \mathrm{LMDA}, \mathrm{RK}^{+}$, and $\mathrm{RNa}^{+}$at $3 \mathrm{~d}$ and for LFW, LWSC, RWSC, and $\mathrm{RNa}^{+}$at $7 \mathrm{~d}$ of treatment (Table 1). No significant treatment by cultivar interactions was shown for all traits except for LMDA at $3 \mathrm{~d}$ and for LP, RDW, and $\mathrm{RK}^{+}$at $7 \mathrm{~d}$ of treatment (Table 1).

Treatment efFects on Leaves aCross two Cultivars. Waterlogging alone increased LMDA at $3 \mathrm{~d}$ of treatment, whereas salinity alone and simultaneous waterlogging and salinity significantly decreased HT, LFW, LDW, LN, LC, $\mathrm{LK}^{+}$, and increased LWSC, LMDA, and $\mathrm{LNa}^{+}$, compared with the control (Tables 2 and 3). At $7 \mathrm{~d}, \mathrm{~W}$ decreased LWSC and increased LP, and both S and WS significantly decreased HT, LFW, LN, LC, and $\mathrm{LK}^{+}$, compared with the control (Tables 2 and 3). Furthermore, LDW,

Table 1. Analysis of variances for plant height (HT), leaf fresh weight (LFW), leaf dry weight (LDW), leaf chlorophyll (Chl), leaf water-soluble carbohydrate (LWSC), leaf malondialdehyde (LMDA), leaf nitrogen (LN), leaf carbon (LC), leaf phosphorous (LP), leaf potassium (LK ${ }^{+}$), leaf sodium $\left(\mathrm{LNa}^{+}\right)$, root fresh weight (RFW), root dry weight (RDW), root water-soluble carbohydrate (RWSC), root malondialdehyde (LMDA), root nitrogen $(\mathrm{RN})$, root carbon $(\mathrm{RC})$, root phosphorous (RP), root potassium $\left(\mathrm{RK}^{+}\right)$, and root sodium (RNa ${ }^{+}$content in two perennial ryegrass cultivars at 3 and $7 \mathrm{~d}$ of salinity treatment.

\begin{tabular}{|c|c|c|c|c|c|c|c|c|c|c|c|c|c|c|c|c|c|c|c|c|c|}
\hline Day & Variance & HT & LFW & LDW & Chl & LWSC & LMDA & $\mathrm{LN}$ & $\mathrm{LC}$ & LP & $\mathrm{LK}^{+}$ & $\mathrm{LNa}^{+}$ & RFW & RDW & RWSC & RMDA & $\mathrm{RN}$ & $\mathrm{RC}$ & RP & $\mathrm{RK}^{+}$ & $\mathrm{RNa}^{+}$ \\
\hline \multirow[t]{2}{*}{3} & Treatment (T) & * & $* * *$ & $* *$ & NS & $* * *$ & * & $* * *$ & $* * *$ & $* *$ & $* * *$ & $* * *$ & NS & NS & $* *$ & $* *$ & NS & NS & $*$ & $* *$ & $* * *$ \\
\hline & $\mathrm{T} \times \mathrm{CR}$ & NS & NS & NS & NS & NS & $* *$ & NS & NS & NS & NS & NS & NS & $\mathrm{Ns}$ & NS & NS & NS & NS & NS & NS & NS \\
\hline & $\mathrm{CR}$ & NS & * & NS & NS & $*$ & NS & NS & NS & NS & NS & NS & NS & NS & $* *$ & NS & NS & NS & NS & NS & $*$ \\
\hline & $\mathrm{T} \times \mathrm{CR}$ & NS & NS & NS & NS & NS & NS & NS & NS & $*$ & NS & NS & NS & * & NS & NS & NS & NS & NS & $*$ & NS \\
\hline
\end{tabular}

Ns, $*, * *, * * *$ Nonsignificant or significant at $P<0.05,0.01$, and 0.001 , respectively.

Table 2. Treatment effects on plant height (HT), leaf fresh weight (LFW), leaf dry weight (LDW), leaf chlorophyll (Chl), leaf water-soluble carbohydrate (LWSC), and leaf malondialdehyde (LMDA) content across two perennial ryegrass cultivars by split-plot analysis of variance.

\begin{tabular}{|c|c|c|c|c|c|c|c|}
\hline \multirow[b]{2}{*}{ Day } & \multirow[b]{2}{*}{ Treatment $^{z}$} & $\mathrm{HT}(\mathrm{cm})$ & LFW (g) & LDW (g) & Chl $\left(\mathrm{mg} \cdot \mathrm{g}^{-1}\right)$ & LWSC $\left(\mathrm{mg} \cdot \mathrm{g}^{-1}\right)$ & LMDA $\left(\mu \mathrm{mol} \cdot \mathrm{g}^{-1} \mathrm{FW}\right)$ \\
\hline & & \multicolumn{6}{|c|}{ Mean \pm SD } \\
\hline \multirow[t]{3}{*}{3} & $\mathrm{CL}$ & $1.9 \pm 0.73 \mathrm{a}^{\mathrm{y}}$ & $8.5 \pm 0.41 \mathrm{a}$ & $1.2 \pm 0.05 \mathrm{a}$ & $1.5 \pm 0.18$ & $13.0 \pm 2.0 \mathrm{~b}$ & $5.0 \pm 1.5 \mathrm{~b}$ \\
\hline & W & $2.1 \pm 0.42 \mathrm{a}$ & $8.4 \pm 0.47 \mathrm{a}$ & $1.1 \pm 0.06 \mathrm{a}$ & $1.4 \pm 0.24$ & $13.5 \pm 1.6 \mathrm{~b}$ & $10.9 \pm 6.1 \mathrm{a}$ \\
\hline & WS & $0.58 \pm 0.26 \mathrm{~b}$ & $4.8 \pm 0.49 b$ & $0.91 \pm 0.12 \mathrm{~b}$ & $1.5 \pm 0.16$ & $22.1 \pm 1.3 \mathrm{a}$ & $9.8 \pm 5.2 \mathrm{a}$ \\
\hline \multirow[t]{3}{*}{7} & $\mathrm{CL}$ & $4.7 \pm 0.69 \mathrm{a}$ & $9.6 \pm 0.48 \mathrm{a}$ & $1.4 \pm 0.14 \mathrm{a}$ & $1.6 \pm 0.12 \mathrm{a}$ & $19.1 \pm 2.4 \mathrm{c}$ & $5.1 \pm 2.2 \mathrm{~b}$ \\
\hline & W & $5.3 \pm 1.31 \mathrm{a}$ & $9.8 \pm 0.76 \mathrm{a}$ & $1.4 \pm 0.08 \mathrm{a}$ & $1.5 \pm 0.19 \mathrm{a}$ & $14.6 \pm 3.8 \mathrm{~d}$ & $4.9 \pm 0.66 b$ \\
\hline & WS & $1.2 \pm 0.24 \mathrm{~b}$ & $5.8 \pm 0.39 b$ & $1.2 \pm 0.11 \mathrm{~b}$ & $1.1 \pm 0.13 \mathrm{~b}$ & $20.3 \pm 2.3 \mathrm{bc}$ & $7.1 \pm 1.7 \mathrm{~b}$ \\
\hline
\end{tabular}

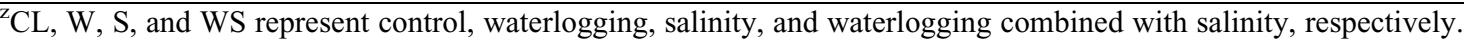

${ }^{\mathrm{y}}$ Means followed by the same letter within a column for a given day are not significantly different at $P<0.05$. 
Chl, and LP were reduced by 14\%, 31\%, and 18\% under $7 \mathrm{~d}$ of WS, respectively. A significant higher $\mathrm{LNa}^{+}$was found in WS than in $\mathrm{S}$ at both 3 and $7 \mathrm{~d}$ of treatment.

Treatment effects on roots across two Cultivars. Waterlogging did not affect root traits (Table 4). Compared with the control, W or WS decreased $\mathrm{RK}^{+}$and increased RWSC, RMDA, and $\mathrm{RNa}^{+}$at both 3 and $7 \mathrm{~d}$ of treatment. The reduced RFW and RDW were found only at $7 \mathrm{~d}$ of $\mathrm{W}$ and WS. An increase in RP was noted at $3 \mathrm{~d}$ of WS and at both 3 and $7 \mathrm{~d}$ of $\mathrm{W}$ and WS. At $7 \mathrm{~d}$, WS had higher $\mathrm{RK}^{+}$and $\mathrm{RNa}^{+}$than that of S. Specifically, at $7 \mathrm{~d}, \mathrm{RNa}^{+}$increased by 7.2-fold under WS and 6.1-fold under S, compared with the control.

RESPONSES OF INDIVIDUAL CULTIVARS TO TREATMENTS. Waterlogging alone did not alter HT, LFW, LDW, RFW, and RDW, except for an increased HT and RDW in 'Catalina' and decreased RDW in 'Inspire' exposed to $7 \mathrm{~d}$ of treatment, compared with the control (Fig. 1). HT, LFW, and LDW decreased under S or WS, except for an unchanged LDW in 'Inspire' at $7 \mathrm{~d}$ of treatment. At $3 \mathrm{~d}, \mathrm{RFW}$ and RDW were unaffected by $\mathrm{S}$ or WS but were significantly reduced at $7 \mathrm{~d}$ of treatments in 'Inspire' but not in 'Catalina' (Fig. 1). At $7 \mathrm{~d}$, the RDW of 'Inspire' was $28 \%, 30 \%$, and $36 \%$ lower compared with the control in $\mathrm{W}, \mathrm{S}$, and WS, respectively, whereas no differences in RDW were found among these three treatments. For 'Catalina', RDW was not different among the control, S, and WS treatments at $7 \mathrm{~d}$.

Table 3. Treatment effects on leaf nitrogen (LN), leaf carbon (LC), leaf phosphorous (LP), leaf potassium $\left(\mathrm{LK}^{+}\right)$, and leaf sodium $\left(\mathrm{LNa}^{+}\right)$content across two perennial ryegrass cultivars by splitplot analysis of variance.

\begin{tabular}{lcccccc}
\hline & & LN & LC & LP & LK $^{+}$ & LNa $^{+}$ \\
\cline { 2 - 6 } Day & Treatment & \\
\hline 3 & CL & $3.4 \pm 0.17 \mathrm{a}^{\mathrm{y}}$ & $41.9 \pm 2.2 \mathrm{a}$ & $7.4 \pm 0.66 \mathrm{a}$ & $35.4 \pm 2.1 \mathrm{a}$ & $2.4 \pm 0.78 \mathrm{c}$ \\
& $\mathrm{W}$ & $3.4 \pm 0.21 \mathrm{a}$ & $41.3 \pm 1.9 \mathrm{a}$ & $7.7 \pm 0.36 \mathrm{a}$ & $35.6 \pm 2.1 \mathrm{a}$ & $2.2 \pm 0.03 \mathrm{c}$ \\
& $\mathrm{S}$ & $2.8 \pm 0.17 \mathrm{~b}$ & $38.7 \pm 2.2 \mathrm{~b}$ & $6.0 \pm 0.76 \mathrm{~b}$ & $28.6 \pm 2.2 \mathrm{~b}$ & $25.5 \pm 3.6 \mathrm{~b}$ \\
7 & $\mathrm{WS}$ & $2.6 \pm 0.24 \mathrm{~b}$ & $37.0 \pm 1.4 \mathrm{~b}$ & $5.7 \pm 0.50 \mathrm{~b}$ & $28.4 \pm 2.0 \mathrm{~b}$ & $34.0 \pm 6.8 \mathrm{a}$ \\
& $\mathrm{CL}$ & $3.7 \pm 0.23 \mathrm{a}$ & $41.4 \pm 1.1 \mathrm{a}$ & $6.8 \pm 0.74 \mathrm{~b}$ & $33.6 \pm 5.7 \mathrm{a}$ & $1.9 \pm 0.40 \mathrm{c}$ \\
& $\mathrm{W}$ & $3.8 \pm 0.13 \mathrm{a}$ & $42.1 \pm 1.1 \mathrm{a}$ & $8.0 \pm 0.27 \mathrm{a}$ & $35.3 \pm 0.7 \mathrm{a}$ & $2.1 \pm 0.15 \mathrm{c}$ \\
& $\mathrm{S}$ & $2.8 \pm 0.23 \mathrm{~b}$ & $37.5 \pm 1.4 \mathrm{~b}$ & $5.9 \pm 0.57 \mathrm{bc}$ & $24.1 \pm 2.5 \mathrm{~b}$ & $33.1 \pm 2.6 \mathrm{~b}$ \\
& $\mathrm{WS}$ & $2.7 \pm 0.15 \mathrm{~b}$ & $36.5 \pm 1.4 \mathrm{~b}$ & $5.6 \pm 1.30 \mathrm{c}$ & $24.7 \pm 7.1 \mathrm{~b}$ & $46.0 \pm 9.6 \mathrm{a}$ \\
\hline
\end{tabular}

${ }^{\mathrm{z}} \mathrm{CL}, \mathrm{W}, \mathrm{S}$, and WS represent control, waterlogging, salinity, and waterlogging combined with salinity, respectively.

${ }^{\mathrm{y}}$ Means followed by the same letter within a column for a given day are not significantly different at $P<0.05$.
A decline in Chl was found only under WS at $7 \mathrm{~d}$ of treatment for both cultivars (Fig. 2). LWSC and RWSC were unaffected by W alone except for a decreased value in 'Inspire' at $7 \mathrm{~d}$ of treatment, but were significantly increased under $\mathrm{S}$ and WS except for an unchanged LWSC at $7 \mathrm{~d}$ of WS in 'Catalina' (Fig. 2). At $7 \mathrm{~d}$, RWSC increased by 2.5- and 2.3-fold for 'Inspire' and by 1.8- and 1.7-fold for 'Catalina' under S and WS, respectively. Waterlogging did not alter LMDA and RMDA, with the exception of an increased LMDA for 'Catalina' at $3 \mathrm{~d}$ of treatment and an increased LMDA for 'Inspire' at $7 \mathrm{~d}$ of S, compared with the control. LMDA increased by $96.8 \%$ and $80.7 \%$ for 'Inspire' and by 1.0 - and 1.5-fold for 'Catalina' exposed to 3 and $7 \mathrm{~d}$ of S, respectively; while a 1.7-fold increase in LMDA was also observed in 'Catalina' at $7 \mathrm{~d}$ of WS, compared with the control (Fig. 3). For 'Inspire', RMDA increased by $57.5 \%$ and $64.2 \%$ at $3 \mathrm{~d}$ and by $48.9 \%$ and $47.4 \%$ at $7 \mathrm{~d}$ of $\mathrm{S}$ and WS, respectively, while RMDA increased by $63.3 \%$ at $3 \mathrm{~d}$ of $\mathrm{S}$ and by $67.3 \%$ at $7 \mathrm{~d}$ of WS for 'Catalina', compared with their respective controls.

The values of LN and LC were unaffected by W but were reduced in both cultivars exposed to 3 and $7 \mathrm{~d}$ of S or WS, except for Inspire at $3 \mathrm{~d}$ of S (Fig. 3). LP was reduced in Inspire at 3 and $7 \mathrm{~d}$ of S or WS (Fig. 3). Significant reductions in LK were shown at $3 \mathrm{~d}$ of S and WS for both cultivars (Fig. 3). $\mathrm{LK}^{+}$decreased by $34 \%$ for 'Inspire' exposed to $7 \mathrm{~d}$ of WS and by $38 \%$ for 'Catalina' at $7 \mathrm{~d}$ of $\mathrm{S}$. Dramatic increases in $\mathrm{LNa}^{+}$were observed at 3 and $7 \mathrm{~d}$ of $\mathrm{S}$ and WS for both cultivars. Specifically, $\mathrm{LNa}^{+}$increased by 16.8- and 24.5-fold for 'Inspire' and by 15.4 - and 21.5 -fold for 'Catalina' at $7 \mathrm{~d}$ of $\mathrm{S}$ and WS, respectively, compared with their relative controls. At $7 \mathrm{~d}$, the WS treatment plants had $\approx 44 \%$ and $35 \%$ higher $\mathrm{LNa}^{+}$than that of S for 'Inspire' and 'Catalina', respectively.

$\mathrm{RN}$ and $\mathrm{RC}$ remained unchanged for both cultivars except for a lower value of $\mathrm{RN}$ and $\mathrm{RC}$ noted at $7 \mathrm{~d}$ of $\mathrm{W}$ for Catalina, compared with the control (Fig. 4). Waterlogging did not change RP in either cultivar (Fig. 4). Significant increases in RP were shown at $3 \mathrm{~d}$ of S and WS for 'Inspire'

Table 4. Treatment effects on root fresh weight (RFW), root dry weight (RDW), root water-soluble carbohydrate (RWSC), root malondialdehyde (RMDA), root phosphorous (RP), root potassium $\left(\mathrm{RK}^{+}\right)$, and root sodium $\left(\mathrm{RNa}^{+}\right)$content across two perennial ryegrass cultivars by split-plot analysis of variance.

\begin{tabular}{|c|c|c|c|c|c|c|c|c|}
\hline \multirow[b]{3}{*}{ Day } & \multirow[b]{3}{*}{ Treatment $^{z}$} & \multirow{3}{*}{ RFW (g) } & \multirow{3}{*}{ RDW (g) } & \multirow{3}{*}{ RWSC $\left(\mathrm{mg} \cdot \mathrm{g}^{-1}\right)$} & \multirow{2}{*}{$\begin{array}{c}\text { RMDA } \\
\left(\mu \mathrm{mol} \cdot \mathrm{g}^{-1} \text { fresh weight }\right)\end{array}$} & $\mathrm{RP}$ & $\mathrm{RK}^{+}$ & $\mathrm{RNa}^{+}$ \\
\hline & & & & & & \multicolumn{3}{|c|}{$\mathrm{mg} \cdot \mathrm{g}^{-1}$ dry weight } \\
\hline & & & & & Mean \pm SD & & & \\
\hline \multirow[t]{4}{*}{3} & $\mathrm{CL}$ & $3.8 \pm 0.72^{y}$ & $0.52 \pm 0.13$ & $15.9 \pm 2.5 b$ & $4.3 \pm 0.61 \mathrm{~b}$ & $3.4 \pm 0.27 \mathrm{~b}$ & $22.4 \pm 2.5 \mathrm{a}$ & $3.8 \pm 1.4 \mathrm{~b}$ \\
\hline & W & $3.9 \pm 0.73$ & $0.57 \pm 0.10$ & $16.1 \pm 1.7 \mathrm{~b}$ & $5.0 \pm 0.62 \mathrm{~b}$ & $3.5 \pm 0.29 b$ & $21.2 \pm 3.5 \mathrm{a}$ & $4.0 \pm 0.68 b$ \\
\hline & $\mathrm{S}$ & $3.4 \pm 1.04$ & $0.52 \pm 0.14$ & $33.8 \pm 4.0 \mathrm{a}$ & $6.9 \pm 1.4 \mathrm{a}$ & $3.8 \pm 0.70 \mathrm{ab}$ & $14.4 \pm 2.6 b$ & $19.4 \pm 2.9 \mathrm{a}$ \\
\hline & WS & $3.1 \pm 0.59$ & $0.47 \pm 0.12$ & $33.8 \pm 3.7 \mathrm{a}$ & $6.1 \pm 1.3 \mathrm{a}$ & $4.3 \pm 0.67 \mathrm{a}$ & $17.3 \pm 2.2 \mathrm{~b}$ & $19.1 \pm 3.5 \mathrm{a}$ \\
\hline \multirow[t]{4}{*}{7} & $\mathrm{CL}$ & $4.7 \pm 0.94 \mathrm{a}$ & $0.65 \pm 0.17 \mathrm{a}$ & $16.2 \pm 5.3 b$ & $4.6 \pm 1.4 \mathrm{~b}$ & $3.5 \pm 0.35 b$ & $22.8 \pm 3.0 \mathrm{a}$ & $3.4 \pm 0.55 \mathrm{c}$ \\
\hline & W & $4.3 \pm 0.23 \mathrm{a}$ & $0.63 \pm 0.11 \mathrm{a}$ & $14.7 \pm 3.2 \mathrm{~b}$ & $6.1 \pm 2.3 \mathrm{ab}$ & $3.6 \pm 0.53 \mathrm{~b}$ & $20.2 \pm 3.9 \mathrm{ab}$ & $4.0 \pm 0.65 \mathrm{c}$ \\
\hline & S & $3.1 \pm 0.51 \mathrm{~b}$ & $0.49 \pm 0.10 b$ & $49.7 \pm 7.6 \mathrm{a}$ & $7.0 \pm 1.4 \mathrm{a}$ & $4.5 \pm 0.35 \mathrm{a}$ & $15.3 \pm 2.2 \mathrm{c}$ & $24.1 \pm 2.2 \mathrm{~b}$ \\
\hline & WS & $3.1 \pm 0.68 \mathrm{~b}$ & $0.45 \pm 0.09 \mathrm{~b}$ & $47.3 \pm 8.6 \mathrm{a}$ & $7.3 \pm 1.6 \mathrm{a}$ & $5.1 \pm 0.73 \mathrm{a}$ & $19.0 \pm 2.5 \mathrm{~b}$ & $27.9 \pm 2.8 \mathrm{a}$ \\
\hline
\end{tabular}

${ }^{\mathrm{z}} \mathrm{CL}, \mathrm{W}, \mathrm{S}$, and WS represent control, waterlogging, salinity, and waterlogging combined with salinity, respectively.

${ }^{\mathrm{y}}$ Means followed by the same letter within a column for a given day are not significantly different at $P<0.05$. 

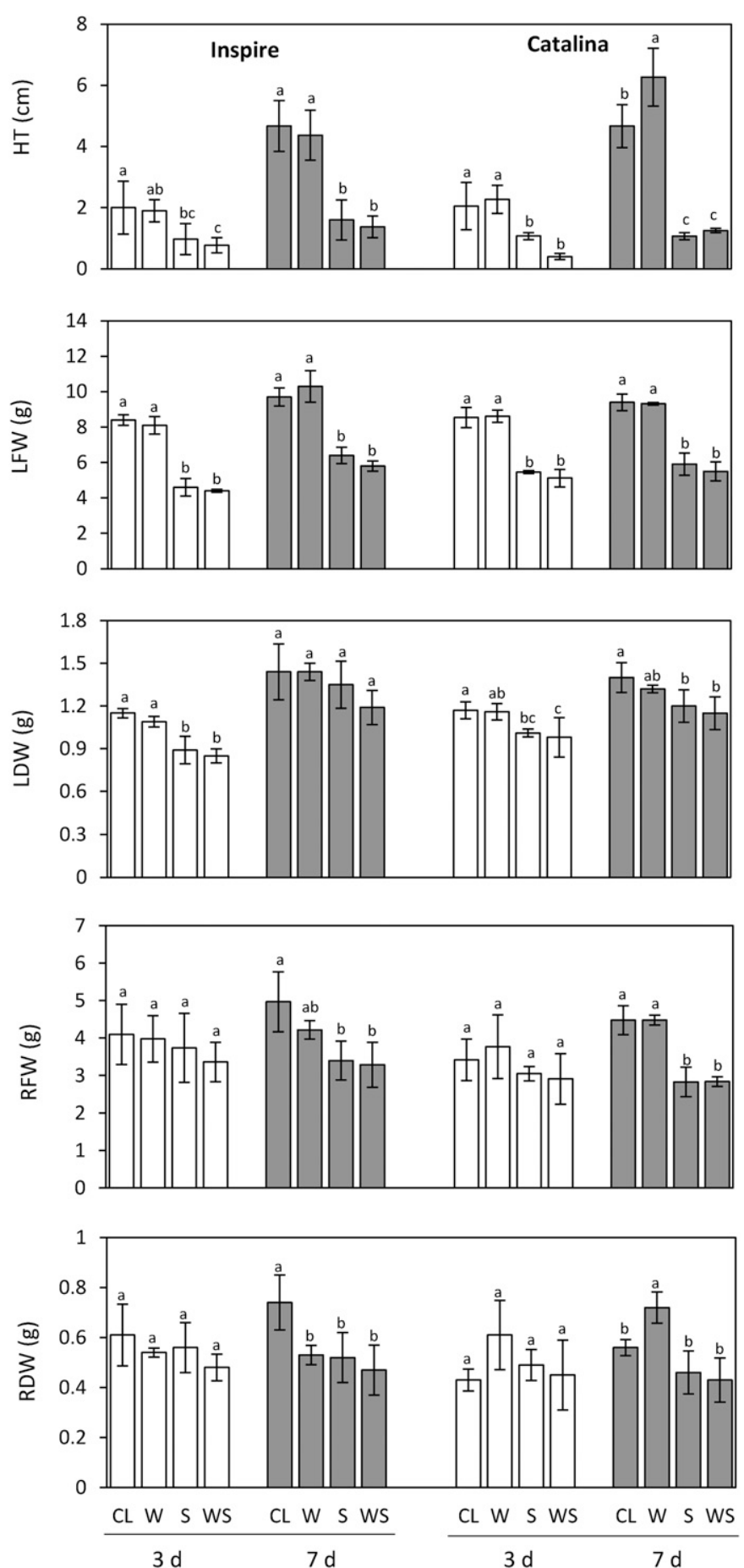

Fig. 1. Plant height (HT), leaf fresh weight (LFW), leaf dry weight (LDW), root fresh weight (RFW), and root dry weight (RDW) as affected by 3 and $7 \mathrm{~d}$ of control (CL), waterlogging (W), salinity (S), and waterlogging plus salinity (WS) in two perennial ryegrass cultivars by split-plot analysis of variance. Comparisons are made among CL, W, S, and WS for a given day and cultivar. Means followed by the same letter are not significantly different at $P<0.05$. Bars indicate SD.

and at $7 \mathrm{~d}$ of WS for 'Catalina'. Waterlogging resulted in a 30\% decrease in $\mathrm{RK}^{+}$for 'Catalina' at $7 \mathrm{~d}$ of treatment (Fig. 4). For 'Inspire', $\mathrm{RK}^{+}$decreased by $29 \%$ and $36 \%$ at $3 \mathrm{~d}$ and $37 \%$ and $21 \%$ at $7 \mathrm{~d}$ of $\mathrm{S}$ and WS, respectively, while for 'Catalina', $\mathrm{RK}^{+}$ decreased by $36 \%$ at $3 \mathrm{~d}$ and $29 \%$ at $7 \mathrm{~d}$ of S, compared with the
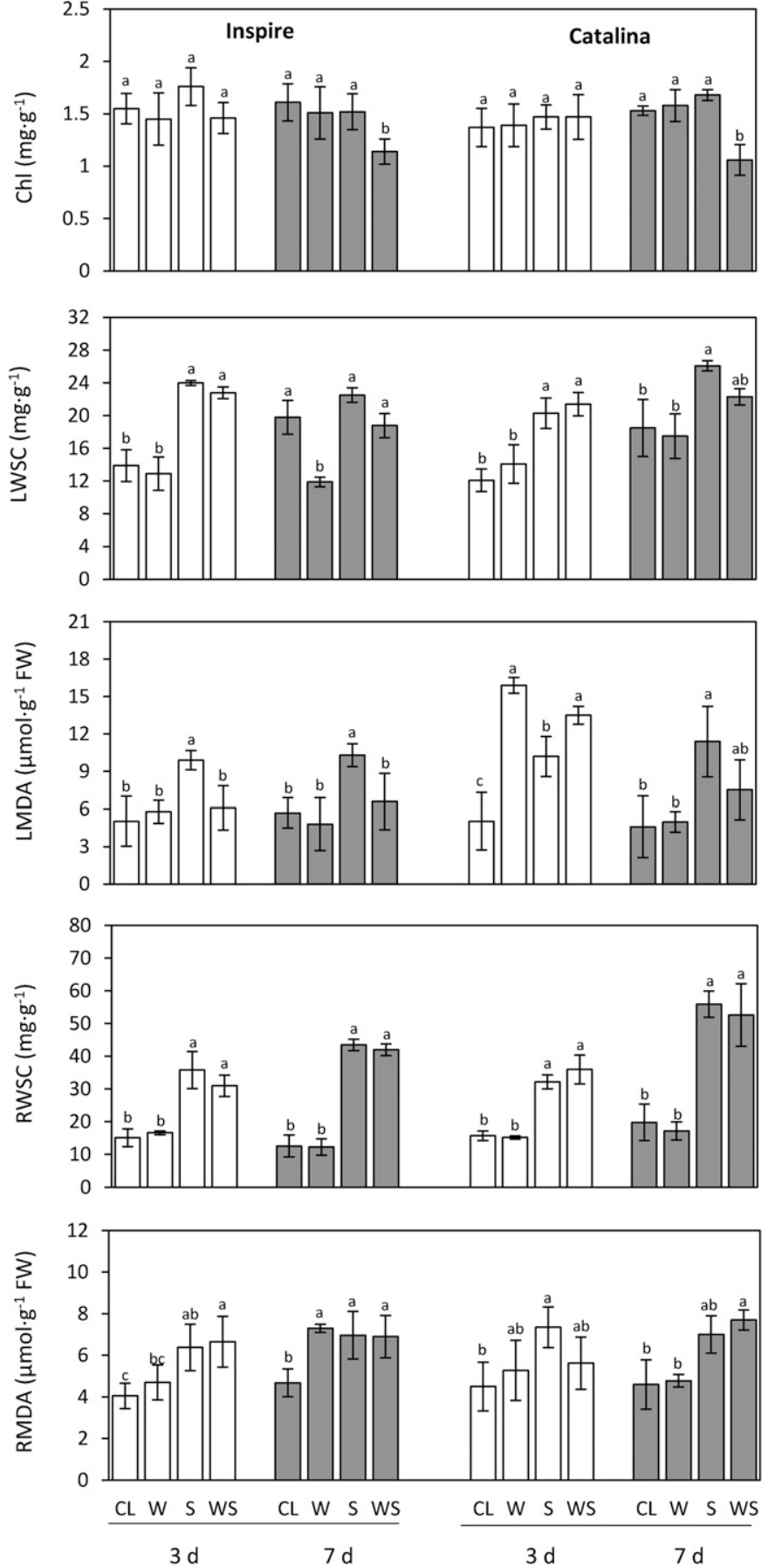

Fig. 2. Chlorophyll (Chl), leaf water-soluble carbohydrate (LWSC), leaf malondialdehyde (LMDA), root water-soluble carbohydrate (RWSC), and root malondialdehyde (RMDA) content as affected by 3 and $7 \mathrm{~d}$ of control (CL), waterlogging (W), salinity (S), and waterlogging plus salinity (WS) in two perennial ryegrass cultivars by split-plot analysis of variance. Comparisons are made among CL, W, S, and WS for a given day and cultivar. Means followed by the same letter are not significantly different at $P<0.05$. Bars indicate SD.

control (Fig. 4). $\mathrm{RNa}^{+}$considerably increased in both cultivars at 3 and $7 \mathrm{~d}$ of $\mathrm{S}$ and WS. At $7 \mathrm{~d}, \mathrm{RNa}^{+}$increased by $5.4-$ and 6.7-fold for 'Inspire' and by 6.7- and 7.6-fold for 'Catalina' under S and WS, respectively, compared with their controls. For 'Inspire', $\approx 21 \%$ higher $\mathrm{LNa}^{+}$was observed under WS 

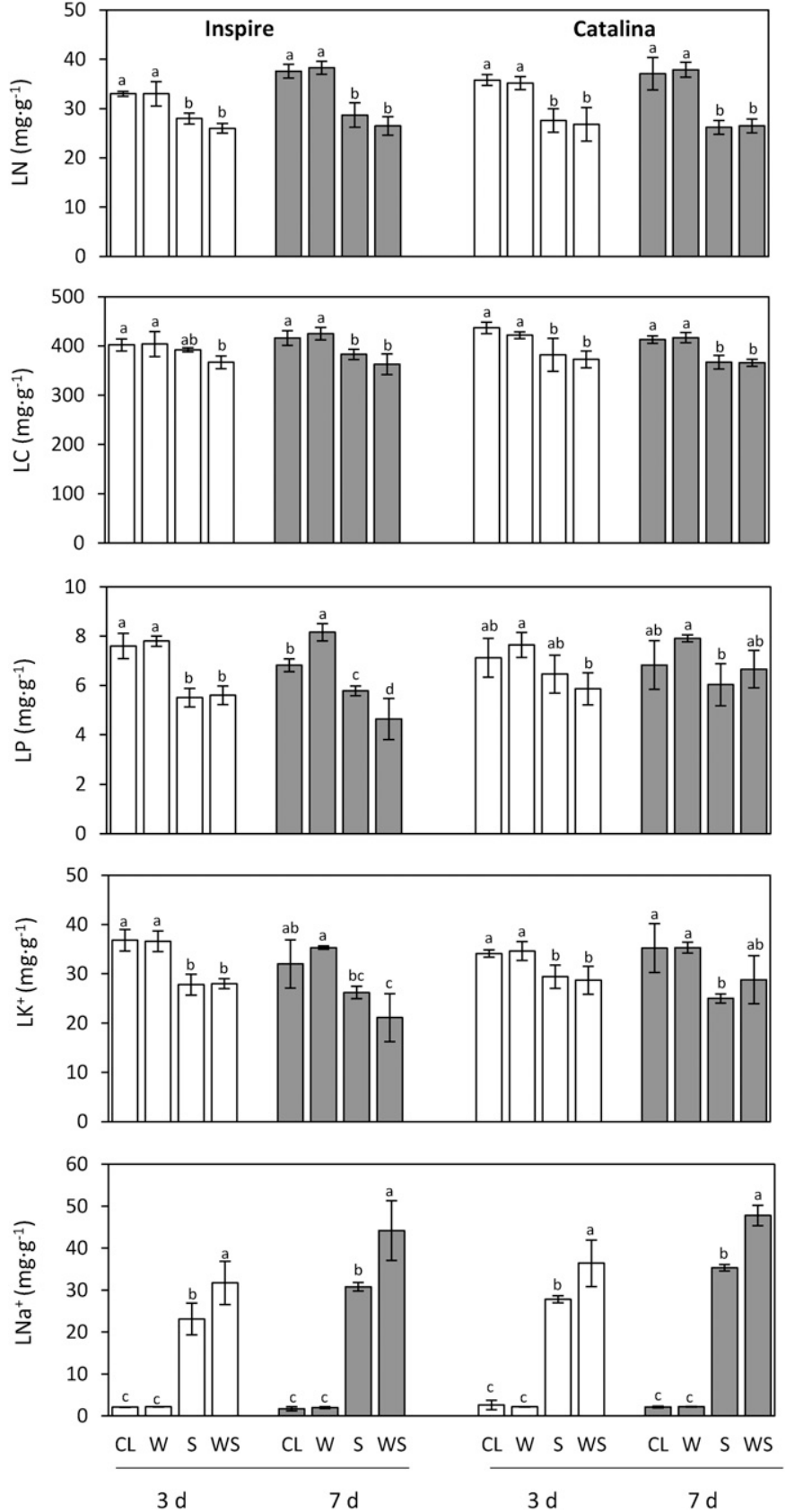

Fig. 3. Leaf nitrogen (LN), leaf carbon (LC), leaf phosphorus (LP), leaf potassium $\left(\mathrm{LK}^{+}\right)$, and leaf sodium $\left(\mathrm{LNa}^{+}\right)$content as affected by 3 and $7 \mathrm{~d}$ of control (CL), waterlogging (W), salinity (S), and waterlogging plus salinity (WS) in two perennial ryegrass cultivars by split-plot analysis of variance. Comparisons are made among $\mathrm{CL}, \mathrm{W}, \mathrm{S}$, and $\mathrm{WS}$ for a given day and cultivar. Means followed by the same letter are not significantly different at $P<0.05$. Bars indicate SD.

compared with $\mathrm{S}$ at $7 \mathrm{~d}$ of treatment, but $\mathrm{LNa}^{+}$did not differ between S and WS for 'Catalina'.

\section{Discussion}

Higher growth rate, low uptake of $\mathrm{Na}^{+}$, and higher ratio of $\mathrm{K}^{+} / \mathrm{Na}^{+}$have been associated with salinity tolerance in some plant species (Azadi et al., 2011; Tang et al., 2013a, 2013b; Thalji and Shalaldeh, 2007). Either slow or higher growth contributes
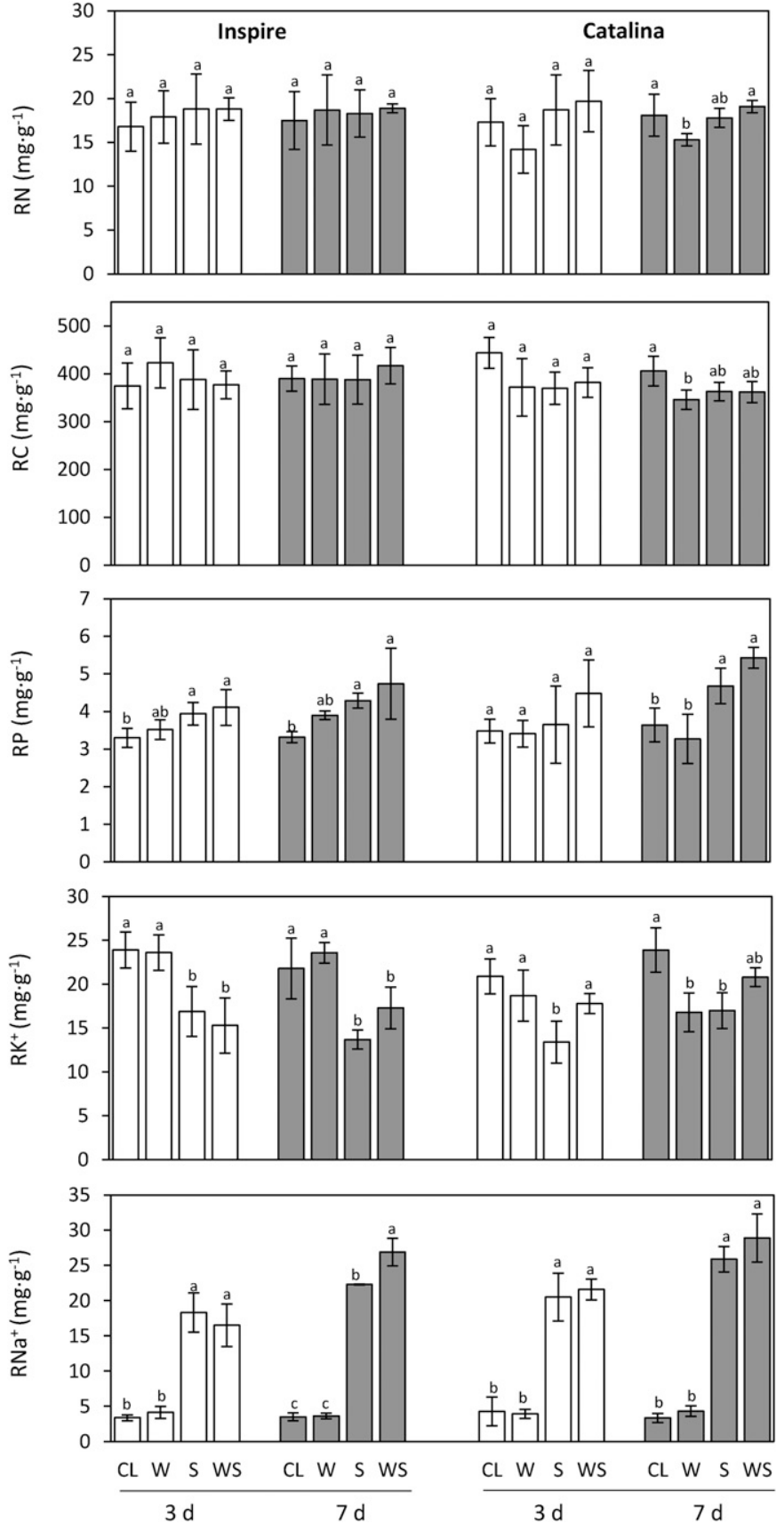

Fig. 4. Root nitrogen ( $R N)$, root carbon (RC), root phosphorus (RP), root potassium $\left(\mathrm{RK}^{+}\right)$, and root sodium $\left(\mathrm{RNa}^{+}\right)$content as affected by 3 and $7 \mathrm{~d}$ of control (CL), waterlogging (W), salinity (S), and waterlogging plus salinity (WS) in two perennial ryegrass cultivars by split-plot analysis of variance. Comparisons are made among CL, W, S, and WS for a given day and cultivar. Means followed by the same letter are not significantly different at $P<0.05$. Bars indicate SD.

to submergence tolerance (Bailey-Serres and Voesenek, 2008). Our previous studies showed that 'Catalina' maintained relatively higher LDW and leaf $\mathrm{K}^{+} / \mathrm{Na}^{+}$than 'Inspire' under $10 \mathrm{~d}$ of $300 \mathrm{~mm} \mathrm{NaCl}$ treatment (Tang et al., 2013b), whereas 'Inspire' had lesser reductions in leaf color and growth rate than 'Catalina' under $7 \mathrm{~d}$ of submergence (Yu et al., 2012). In this study, 'Catalina' had lower leaf $\mathrm{K}^{+} / \mathrm{Na}^{+}$and higher $\mathrm{RK}^{+} / \mathrm{Na}^{+}$ than 'Inspire' at $7 \mathrm{~d}$ of $300 \mathrm{~mm} \mathrm{NaCl}$. Relative to their control, 'Catalina' had slightly higher $\mathrm{RK}^{+}$and lower $\mathrm{LNa}^{+}$and $\mathrm{RNa}^{+}$ 
but higher $\mathrm{LNa}^{+}$than 'Inspire'. Overall, it seemed that 'Catalina' was more salinity tolerant than 'Inspire'. Under $7 \mathrm{~d}$ of $\mathrm{W}$ alone, 'Inspire' had relatively higher LDW but lower RDW than 'Catalina'. Some of the inconsistent responses of two cultivars to salinity or flooding stress in different studies could be due to stress duration ( 7 vs. $10 \mathrm{~d}$ ), severity (waterlogging vs. submergence), as well as plant growth status (young seedlings vs. mature plants).

Plant growth was generally unaffected by W alone but was significantly reduced under $\mathrm{S}$ and WS in perennial ryegrass cultivars. Reductions in HT, LFW, and LDW found at $3 \mathrm{~d}$ and decreases in RFW and RDW noted at $7 \mathrm{~d}$ indicated that inhibition of leaf growth occurred earlier than in the roots exposed to $\mathrm{S}$ or WS. Although WS caused more declines in Chl and had higher $\mathrm{LNa}^{+}$and $\mathrm{RNa}^{+}$than that of $\mathrm{S}$ at $7 \mathrm{~d}$ of treatment, $\mathrm{S}$ and WS had similar effects on growth, carbohydrate, MDA, $\mathrm{N}, \mathrm{C}$, and $\mathrm{P}$ content across the two cultivars. The results suggested that $\mathrm{S}$ stress plays a critical role in decreasing plant growth and nutrient content when perennial ryegrass plants were subjected to WS. In waterlogging-tolerant plants of water mint (Mentha aquatica), the combined effect of WS caused partial alleviation of salinity injury $(150 \mathrm{~mm} \mathrm{NaCl})$ by strong induction of metabolic activities and anatomical responses (Haddadi et al., 2016). However, a waterlogging-tolerant sweet clover showed tolerance to WS by regulating ions but not root porosity (Striker et al., 2015). It appears that plant responses to WS are complex, depending on the plant species, as well as their adaptive tolerance to either $\mathrm{W}$ or $\mathrm{S}$ alone.

MDA content is an indicator of lipid peroxidation. Significant increases in LMDA for 'Catalina' at $3 \mathrm{~d}$ of $\mathrm{W}$ and an increase in RMDA for 'Inspire' at $7 \mathrm{~d}$ of $\mathrm{W}$ indicated that lipid peroxidation occurred in the plants under W alone. Similar results of growth and shoot and root MDA content were found in both turf and forage types of perennial ryegrass exposed to $7 \mathrm{~d}$ of W (Liu and Jiang, 2015). With an extended period of W stress $(21 \mathrm{~d})$, reductions in growth were shown in creeping bentgrass cultivars; however, root MDA remained unchanged between the control and stressed plants (Wang and Jiang, $2007 \mathrm{~b}$ ). It seems that waterlogging-induced lipid peroxidation varies with species and cultivars, stress duration, and intensity. In this study, salinity stress increased leaf and root MDA content in both cultivars of perennial ryegrass, and the results were consistent with reports in turfgrass and other plant species exposed to various salinity stresses (Chen and Ye, 2014; Hu et al., 2012; Xu and Fujiyama, 2013). Similar levels of MDA between $\mathrm{S}$ and WS or even lower MDA accumulation under WS indicated that the degree of lipid peroxidation induced by $\mathrm{S}$ was severe and comparable to that under WS in the two perennial ryegrass cultivars.

Waterlogging did not affect leaf and root $\mathrm{Na}^{+}$and $\mathrm{K}^{+}$content in either of the perennial ryegrass cultivars. The results were consistent with the findings in two seepweed (Suaeda salsa) populations under waterlogged conditions (Song et al., 2011). The increases in $\mathrm{Na}^{+}$and decreases in $\mathrm{K}^{+}$content associated with changes in shoot biomass have been found in many plant species exposed to S or WS (Aini et al., 2012; Barrett-Lennard and Shabala, 2013; Bhuiyan et al., 2015; Horchani et al., 2010; Tang et al., 2013a). It seems that ion regulation played a vital role in the differences in plant growth between the tolerant and sensitive species under saline or saline combined with waterlogging conditions (Jenkins et al., 2010). For example, a lower $\mathrm{Na}^{+}$content contributed to greater tolerance to WS in the tolerant narrowleaf trefoil (Lotus tenuis) than in the sensitive birdsfoot trefoil (Lotus corniculatus) (Teakle et al., 2006). In this study, greater uptake of $\mathrm{Na}^{+}$in the leaves and roots under $7 \mathrm{~d}$ of WS compared with that under $\mathrm{S}$ was not consistent with the differences in leaf and root dry weight between WS and S. Our results supported the idea that $\mathrm{Na}^{+}$content was not often associated with the degree of salinity tolerance found in other species (Munns and James, 2003).

Short-term W had no effect on WSC, but S and WS significantly increased WSC for both cultivars. This accumulation of carbohydrates may enable plants to sustain growth under saline conditions by increasing osmotic adjustment, balancing the excess accumulated ions, and protecting biomolecules (Messedi et al., 2006). The increased carbohydrate had been found to be related to salinity tolerance of rice [Oryza sativa (Zhang et al., 2012)] and sunflower [Helianthus annuus (Ashraf and Tufail, 1995)]. However, when tomato (Solanum lycopersicum) plants were subjected to WS, sugar content significantly decreased concurrently with declines in shoot and root biomass (Horchani et al., 2010). Carbohydrates also remained unchanged in leaves but increased in the roots in other plant species (Hussin et al., 2013), but this effect was unrelated to salinity tolerance (Praxedes et al., 2011). By comparing perennial ryegrass cultivars, the extent of carbohydrate alterations in roots was consistent with changes in $\mathrm{Na}^{+}$content. The results suggested that inhibition of growth interfered by an uptake of $\mathrm{Na}^{+}$under salinity stress may reduce the demand for carbohydrates, leading to elevated levels of carbohydrates under $\mathrm{S}$ or WS in perennial ryegrass. However, the role of carbohydrate in tolerance to $\mathrm{S}$ and WS needs further investigation in turfgrass species.

The content of N, C, and P was unaffected for both cultivars of perennial ryegrass exposed to $\mathrm{W}$ alone except for a reduced $\mathrm{RN}$ and $\mathrm{RC}$ at $7 \mathrm{~d}$ for Catalina, suggesting that short-term $\mathrm{W}$ had little effect on these nutrients, consistent with the patterns of growth. Salinity stress decreased the uptake and concentration of $\mathrm{NO}_{3}{ }^{-}$and $\mathrm{P}$ in plant tissues (Khan and Srivastava, 1998; López-Berenguer et al., 2007). Reductions in $\mathrm{NO}_{3}{ }^{-}$concentration may contribute to the overall reduction in total $\mathrm{N}$ content (Hussin et al., 2013). In this study, reduced LN for both cultivars under $\mathrm{S}$ or WS and decreased leaf $\mathrm{P}$ for Inspire may lead to declines in leaf growth. More reductions in leaf $\mathrm{P}$ were noted under $3 \mathrm{~d}$ of WS compared with $\mathrm{S}$ for 'Inspire', but such patterns were not observed in 'Catalina'. Unlike leaves, RN and $\mathrm{RC}$ remained unchanged and $\mathrm{P}$ content even increased by $\mathrm{S}$ or WS, demonstrating differential responses of leaf and root $\mathrm{N}$, $\mathrm{C}$, and $\mathrm{P}$ in response to $\mathrm{S}$ or WS in perennial ryegrass. In broccoli (Brassica oleracea var. italica), LN increased and RN was unaffected by increasing salinity stress, but root total $\mathrm{P}$ decreased and leaf total $\mathrm{P}$ was unaffected under the same condition (López-Berenguer et al., 2007). In bluegreen saltbush (Atriplex nummularia), total $\mathrm{N}$ content and the $\mathrm{C} / \mathrm{N}$ ratio in both leaves and roots decreased at a lower level of salinity stress, but increased as the intensity of salinity stress was raised. The results indicated that interactions between $\mathrm{S}$ and WS stress and nutrients could largely depend on the plant species, physiological developmental stage, stress intensity, $\mathrm{N}$ and $\mathrm{P}$ availability, etc. The tolerant plants could maintain $\mathrm{C}$ - and $\mathrm{N}$-assimilation processes in equilibrium through well-coordinated regulatory mechanisms to enable optimal growth and development under saline conditions (Hussin et al., 2013). 


\section{Conclusions}

Short-term waterlogging (3-7 d) generally did not affect plant HT, fresh and dry weight, WSC, MDA, N, C, K ${ }^{+}$, and $\mathrm{Na}^{+}$ content in the leaves and roots of perennial ryegrass. Salinity alone or combined with waterlogging significantly decreased plant $\mathrm{HT}$, fresh and dry weight, $\mathrm{N}, \mathrm{C}$, phosphorous, and $\mathrm{K}^{+}$; increased MDA, WSC, and $\mathrm{Na}^{+}$content in the leaves; and decreased root fresh and dry weight, $\mathrm{K}^{+}$content and increased WSC, MDA, phosphorous, and $\mathrm{Na}^{+}$content in the roots exposed to 3 or $7 \mathrm{~d}$ of stress. The two cultivars of perennial ryegrass generally had similar patterns of growth and carbohydrate, nutrient, and lipid peroxidation to waterlogging, salinity, and waterlogging combined with salinity stress. Overall, salinity and waterlogging combined with salinity had similar effects on the growth and physiology of the plants, but caused more severe damage to them than waterlogging alone.

\section{Literature Cited}

Aini, N., E. Mapfumo, E. Rengel, and C. Tang. 2012. Ecophysiological responses of Melaleuca species to dual stresses of water logging and salinity. Intl. J. Plant Physiol. Biochem. 4:52-58.

Ashraf, M. and M. Tufail. 1995. Variation in salinity tolerance in sunflower (Helianthus annuus L.). J. Agron. Soil Sci. 174: 351-362.

Azadi, A., E.M. Hervan, S.A. Mohammadi, F. Moradi, B. Nakhoda, and M. Vahabzade. 2011. Screening of recombinant inbred lines for salinity tolerance in bread wheat (Triticum aestivum L.). Afr. J. Biotechnol. 10:12875-12881.

Bailey-Serres, J. and L.A.C.J. Voesenek. 2008. Flooding stress: Acclimations and genetic diversity. Annu. Rev. Plant Biol. 59 (59):313-339.

Barrett-Lennard, E.G. and S.N. Shabala. 2013. The waterlogging/ salinity interaction in higher plants revisited-Focusing on the hypoxia-induced disturbance to $\mathrm{K}^{+}$homeostasis. Funct. Plant Biol. 40:872-882.

Bhuiyan, M., A. Raman, D. Hodgkins, D. Mitchell, and H. Nicol. 2015. Physiological response and ion accumulation in two grasses, one legume, and one saltbush under soil water and salinity stress. Ecohydrology 8:1547-1559.

Chen, Y. and Y. Ye. 2014. Effects of salinity and nutrient addition on mangrove Excoecaria agallocha. PLoS One 9:e93337.

Dhindsa, R.S., P. Plumb-Dhindsa, and T.A. Thorpe. 1981. Leaf senescence: Correlated with increased leaves of membrane permeability and lipid peroxidation and decreased levels of superoxide dismutase and catalase. J. Expt. Bot. 32:93-101.

Haddadi, B.S., H. Hassanpour, and V. Niknam. 2016. Effect of salinity and waterlogging on growth, anatomical and antioxidative responses in Mentha aquatica L. Acta Physiol. Plant. 38:119.

Heath, R.L. and L. Packer. 1968. Photoperoxidation in isolated chloroplasts. I. Kinetics and stoichiometry of fatty acid peroxidation. Arch. Biochem. Biophys. 125:189-198.

Horchani, F., R. Hajri, H. Khayati, and S. Aschi-Smiti. 2010. Physiological responses of tomato plants to the combined effect of root hypoxia and $\mathrm{NaCl}$ salinity. J. Phytol. 2:36-46.

Huang, B., X. Liu, and J.D. Fry. 1998. Shoot physiological responses to two bent grass cultivars to high temperature and poor soil aeration. Crop Sci. 38:1219-1224.

Hu, L., Z. Huang, S. Liu, and J. Fu. 2012. Growth response and gene expression in antioxidant-related enzymes in two bermudagrass genotypes differing in salt tolerance. J. Amer. Soc. Hort. Sci. 137: 134-143.

Hussin, S., N. Geissler, and H.-W. Koyro. 2013. Effect of NaCl salinity on Atriplex nummularia (L.) with special emphasis on carbon and nitrogen metabolism. Acta Physiol. Plant. 35:1025-1038.
Jenkins, S., E.G. Barrett-Lennard, and Z. Rengel. 2010. Impacts of waterlogging and salinity on puccinellia (Puccinellia ciliata) and tall wheatgrass (Thinopyrum ponticum): Zonation on saltland with a shallow water-table, plant growth, and $\mathrm{Na}^{+}$and $\mathrm{K}^{+}$concentrations in the leaves. Plant Soil 329:91-104.

Jiang, Y. and K. Wang. 2006. Growth, physiological and anatomical responses of creeping bentgrass cultivars to different depths of waterlogging. Crop Sci. 46:2420-2426.

Khan, M. and H. Srivastava. 1998. Changes in growth and nitrogen assimilation in maize plants induced by $\mathrm{NaCl}$ and growth regulators. Biol. Plant. 41:93-99.

Koehler, L.H. 1952. Differentiation of carbohydrates by anthrone reaction rate and color intensity. Anal. Chem. 24:1576-1579.

Liu, M. and Y. Jiang. 2015. Genotypic variation in growth and metabolic responses of perennial ryegrass exposed to short-term waterlogging and submergence stress. Plant Physiol. Biochem. 95:57-64.

López-Berenguer, C., M. Carvajal, C. Garcéa-Viguera, and C.F. Alcaraz. 2007. Nitrogen, phosphorus, and sulfur nutrition in broccoli plants grown under salinity. J. Plant Nutr. 30:18551870 .

Messedi, D., I. Slama, N. Laabidi, T. Ghnaya, A. Savoure, A. Soltani, and C. Abdelly. 2006. Effect of nitrogen deficiency, salinity and drought on proline metabolism in Sesuvium portulacastrum, p. 6572. In: M. Öztürk, Y. Waisel, M.A. Khan, and G. Görk (eds.). Biosaline agriculture and salinity tolerance in plants. Springer, New York, NY.

Munns, R. and R.A. James. 2003. Screening methods for salinity tolerance: A case study with tetraploid wheat. Plant Soil 253:201218.

Munns, R. and M. Tester. 2008. Mechanisms of salinity tolerance. Annu. Rev. Plant Biol. 59:651-681.

Praxedes, S.C., C.F. De Lacerda, T.M. Ferreira, J.T. Prisco, F.M. DaMatta, and E. Gomes-Filho. 2011. Salt tolerance is unrelated to carbohydrate metabolism in cowpea cultivars. Acta Physiol. Plant. 33:887-896.

Shokri, S. and B. Maadi. 2009. Effects of arbuscular mycorrhizal fungus on the mineral nutrition and yield of Trifolium alexandrium plants under salinity stress. J. Agron. 8:79-83.

Song, J., G. Shi, B. Gao, H. Fan, and B. Wang. 2011. Waterlogging and salinity effects on two Suaeda salsa populations. Physiol. Plant. 141:343-351.

Striker, G.G., N.L. Teakle, T.D. Colmer, and E.G. Barrett-Lennard. 2015. Growth responses of Melilotus siculus accessions to combined salinity and root-zone hypoxia are correlated with differences in tissue ion concentrations and not differences in root aeration. Environ. Exp. Bot. 109:89-98.

Tang, J., J.J. Camberato, X. Yu, N. Luo, S. Bian, and Y. Jiang. 2013a. Growth response, carbohydrate and ion accumulation of diverse perennial ryegrass accessions to increasing salinity. Sci. Hort. 154:73-81.

Tang, J., X. Yu, N. Luo, F. Xiao, J.J. Camberato, and Y. Jiang. 2013 b. Natural variation of salinity response, population structure and candidate genes associated with salinity tolerance in perennial ryegrass accessions. Plant Cell Environ. 36:2021-2033.

Teakle, N.L., S. Bowman, E.G. Barrett-Lennard, D. Real, and T.D. Colmer. 2012. Comparisons of annual pasture legumes in growth, ion regulation and root porosity demonstrate that Melilotus siculus has exceptional tolerance to combinations of salinity and waterlogging. Environ. Exp. Bot. 77:175-184.

Teakle, N.L., D. Real, and T.D. Colmer. 2006. Growth and ion relations in response to combined salinity and waterlogging in the perennial forage legumes Lotus corniculatus and Lotus tenuis. Plant Soil 289:369-383.

Thalji, T. and G. Shalaldeh. 2007. Screening wheat and barley genotype for salinity resistance. J. Agron. 6:75-78.

Uddin, M.K., A.S. Juraimi, M.R. Ismail, M.A. Hossain, R. Othman, and A.A. Rahim. 2012. Physiological and growth responses of six 
turfgrass species relative to salinity tolerance. 3 Jan. 2017. $<$ http:// dx.doi.org/10.1100/2012/905468>.

Wang, K. and Y. Jiang. 2007a. Waterlogging tolerance of kentucky bluegrass cultivars. HortScience 42:386-390.

Wang, K. and Y. Jiang. 2007b. Antioxidant responses of creeping bentgrass roots to waterlogging. Crop Sci. 47:232-238.

Wellburn, A.R. 1994. The spectral determination of chlorophylls a and $\mathrm{b}$, as well as total carotenoids, using various solvents with spectrophotometers of different resolution. J. Plant Physiol. 144:307-313.

$\mathrm{Xu}$, R.M.Y. and H. Fujiyama. 2013. Lipid peroxidation and antioxidative enzymes of two turfgrass species under salinity stress. Pedosphere 23:213-222.

Yu, X., N. Luo, J. Yan, J. Tang, S. Liu, and Y. Jiang. 2012. Differential growth response and carbohydrate metabolism of global collection of perennial ryegrass accessions to submergence and recovery following de-submergence. J. Plant Physiol. 169:1040-1049.

Zhang, Q., A.J. Zuk, and K. Rue. 2013. Salinity ( $\mathrm{NaCl})$, waterlogging, and their combined effects on germination and seedling growth of four turfgrass species. Appl. Turfgrass Sci. doi: 10.1094/ATS-20130226-01-RS.

Zhang, Z.-H., L. Qiang, H.-X. Song, X.-M. Rong, and A.M. Ismail. 2012. Responses of different rice (Oryza sativa L.) genotypes to salt stress and relation to carbohydrate metabolism and chlorophyll content. Afr. J. Agr. Res. 7:19-27.

Zong, J., Y. Gao, J. Chen, H. Guo, Y. Wang, F. Meng, Y. Jiang, and J. Liu. 2015. Growth and enzymatic activity of four warm-season turfgrass species exposed to waterlogging. J. Amer. Soc. Hort. Sci. 140:151-162. 